\title{
Pengaruh Penerapan Prinsip-Prinsip Good Corporate Governance pada Kinerja Bank Perkreditan Rakyat di Kabupaten Badung
}

\author{
I Wayan Sukardika ${ }^{1}$ \\ Fakultas Ekonomi dan Bisnis \\ Universitas Udayana, Indonesia
}

\author{
I Wayan Gde Wahyu Purna Anggara2 \\ Fakultas Ekonomi Dan Bisnis \\ Universitas Udayana, Indonesia
}

\section{Made Andika Pradnyana Wistawan ${ }^{3}$ \\ Fakultas Ekonomi Dan Bisnis Universitas Udayana, Indonesia}

\begin{abstract}
Surel : edosdka@yahoo.com
ABSTRAK

Transparansi, akuntabilitas, responsibilitas, independensi serta kewajaran merupakan prinsip dasar penerapan GCG. Penelitian ini menggunakan metode survei dengan teknik kuesioner yang di sebar ke 37 BPR. Sampel yang digunakan sebanyak 74 dan masing - masing diambil dua responden dari tiap BPR di bagian keuangan dan di bagian umum yang terdapat di Kabupaten Badung. Penentuan sampel menggunakan metode purposive sampling. Tekik analisis yang digunakan adalah analisis regresi linear sederhana dengan menggunakan SPSS. Penelitian ini menunjukkan hasil bahwa penerapan prinsip - prinsip good corporate governance yang meliputi transparansi, akuntabilitas, responsibilitas, independensi serta kewajaran berpengaruh positif pada kinerja Bank Perkreditan Rakyat di Kabupaten Badung.
\end{abstract}

Kata Kunci: Good Corporate Governance; Balanced Scorecard; Kinerja.

\section{The Effect of Application of Good Corporate Governance Principles on the Performance of Rural Credit Banks in Badung Regency}

\section{ABSTRACT}

Transparency, accountability, responsibility, independence and fairness are basic principles in implementing GCG. This study used a survey method with a questionnaire technique that was distributed to 37 BPRs. The sample used was 74 and each of them was taken two respondents from each BPR in the financial section and in the general section in Badung Regency. Determination of the sample using purposive sampling method. The analysis technique used is a simple linear regression analysis using SPSS. This study shows the results that the application of the principles of good corporate governance which includes transparency, accountability, responsibility, independence and fairness has a positive effect on the performance of Rural Credit Banks in Badung Regency.

Keywords: Good Corporate Governance; Balanced Scorecard; The Performance.

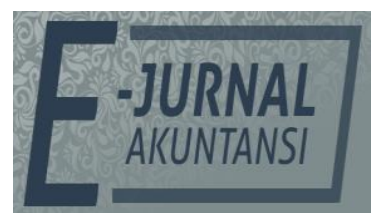

e-ISSN 2302-8556

Vol. 30 No. 8

Denpasar, Agustus 2020

Hal. 2025-2039

DOI:

10.24843/EJA.2020.v30.i08.p10

PENGUTIPAN:

Sukardika, I W., Anggara, I

W. G. W. P. \& Wistawan, I

M. A. P. (2020). Pengaruh

Penerapan Prinsip-Prinsip

Good Corporate Governance pada Kinerja Bank

Perkreditan Rakyat di Kabupaten Badung. E-Jurnal Akuntansi, 30(8), 2025- 2039

RIWAYAT ARTIKEL:

Artikel Masuk: 25 Februari 2020 Artikel Diterima: 19 Juli 2020

Artikel dapat diakses : https://ojs.unud.ac.id/index.php/Akuntansi/index 


\section{PENDAHULUAN}

Kabupaten Badung tercatat memiliki jumlah BPR terbanyak di bali sehingga potensi pemberian kredit kepada masyarakat cukup tinggi. Hal tersebut mewajibkan BPR untuk meningkatkan kinerja usahanya. Jumlah BPR yang tersebar di seluruh Bali menurut Otoritas Jasa Keuangan (OJK) pada tahun 2018 sejumlah 137 BPR, dimana 49 BPR berada di Kabupaten Badung, berdasarkan data PDRB laju pertumbuhan Kabupaten Badung atas dasar harga konstan yang terus mengalami peningkatan tahun 2011 sebesar 1,75\% dan pada tahun 2012 sebesar 2,94\% (www.badungkab.bps.go.id). Dari data yang diperoleh menunjukkan bahwa kinerja yang baik bukanlah suatu hal yang mudah, diperlukan penerapan sistem yang baik serta pengawasan yang efektif. Menurut (Pratiwi 2014) Kinerja suatu bank harus dapat diukur dan menggambarkan kondisi perusahaan pada saat itu, untuk itu diperlukan penilaian dan pengukuran terhadap kinerja yang telah dilakukan perusahaan. Pengukuran kinerja versi Bank Indonesia mengacu pada unsur - unsur Capital, Asset Quality, Management Earning Liquidity (CAMEL). CAMEL digunakan untuk mengukur kinerja keuangan terhadap kegiatan operasionalnya dengan satu tingkat presentase tertentu yang telah ditetapkan sehingga dapat diketahui tingkat kesehatan bank dalam bentuk peningkatan komposit (Brahmananda \& Suputra, 2017).

Pengukuran kinerja perusahaan yang hanya berdasarkan segi keuangan seperti jumlah laba yang diperoleh terkadang tidaklah begitu cocok. Oleh karena itu untuk menilai kinerja perusahaan di bidang perbankan diperlukan banyak pendekatan selain pendekatan keuangan yaitu pendekatan non keuangan yang dapat diterapkan di dunia perbankan (Fitriyani, Tiswiyanti, \& Prasetyo, 2017). Berdasarkan aspek tersebut mengacu pada sistem pengukuran kinerja yang tepat digunakan, terutama di dunia perbankan yang kompetitif seperti sekarang ini, adalah pengukuran kinerja berbasis balanced scorecard yang dirancang oleh Robert S. Kaplan dan David P. Norton (Andriyani \& Asri Dwija 2016). Khozein (2012) menyebutkan bahwa balanced scorecard memiliki keistimewaan dalam hal pengukurannya yang komprehensif dengan menilai kinerja dari empat perspektif, yaitu perspektif keuangan, perspektif pelanggan, perspektif proses bisnis internal, serta perspektif pembelajaran dan pertumbuhan. Penggunaan balanced scorecard pada dapat membantu operasional perusahaan dalam jangka Panjang. Hal tersebut dikarenakan penggunaan balanced scorecard dapat mengukur kinerja baik dari segi finansial dan non finansial (Andriyani \& Asri Dwija, 2016).

Fenomena yang terjadi saat ini adalah perubahan tatanan kehidupan khususnya di bidang ekonomi. Perusahaan perlu mempertimbangkan segala aspek guna mempertahankan konsistensi perusahaan. Adanya pemisahan fungsi antara pemilik (principal) dan pengelola (agent) merupakan penyebab konflik kepentingan (Araujo \& Christiananta, 2013). Pengelola perusahaan yang dipercayakan kepada manajer yang ditunjuk oleh pemegang saham, dalam kenyataannya seringkali terjadi persinggungan tujuan diantara kedua pihak. Manajer dapat saja mengorbankan kepentingan pemegang saham dengan kewenangan yang dimiliki untuk bertindak menguntungkan dirinya sendiri. Pemegang saham (principal) lebih tertarik dengan apa yang telah dicapai oleh 
manajemen (agent) yang mana mereka mengharapkan good news dari investasi yang telah mereka tanamkan di perusahaan tersebut, di lain pihak para manajemen akan berusaha meningkatkan kepentingannya agar memperoleh bonus yang tinggi dengan berusaha memberikan kesan yang baik sehingga selalu dipercaya oleh pemegang saham (principal) serta memperoleh keuntungan yang diharapkan. Teori keagenan menjelaskan untuk mengatasi masalah tersebut perlu memberikan perhatian pada lemahnya penerapan sistem tata kelola perusahaan yang dikenal dengan istilah Good Corporate Governance (GCG) (Peni et al, 2013).

Beberapa kasus yang terjadi pada tahun 2014 perusahaan besar Bank Perkreditan Rakyat di daerah Semarang Jawa Tengah yang bernama BPR Restu Artha Makmur diduga melakukan tindakan pemalsuan data kredit sehingga merugikan asset nasabah (finansial.bisnis.com). Pada tahun 2019 Otoritas Jasa Keuangan (OJK) kembali mencabut izin usaha Bank Perkreditan Rakyat (BPR) Legian yang berada di Denpasar. Pencabutan izin usaha BPR tersebut terjadi karena permasalahan pengelolaan manajemen yang tidak mengacu pada prinsip kehati-hatian dan tata kelola yang baik serta adanya intervensi negatif pemegang saham pengendali dalam kegiatan operasional bank yang mengakibatkan kinerja keuangan BPR tidak memenuhi standar yang ditetapkan (www.cnbcindonesia.com). Tidak lama kemudian pada tahun 2019 tanggal 13 Agustus telah terjadi kembali pencabutan izin usaha PT Bank Perkreditan Rakyat Calliste Bestari di Mengwi-Badung. Kepala Kantor OJK Regional juga mengungkapkan penyebab BPR Calliste Bestari tersebut bermasalah karena adanya praktik perbankan yang tidak sehat, baik oleh pengurus maupun pemegang saham (www.cnbcindonesia.com). Kasus kecurangan perbankan yang diungkapkan dalam Kompas.com yaitu konspirasi kecurangan investasi/ deposito senilai Rp 111 miliar untuk kepentingan pribadi Kepala Cabang Bank Mega Jababeka dan Direktur Keuangan PT Elnusa Tbk pada tahum 2011. Pihak manajemen Elnusa menegaskan bahwa pencarian dana deposito berjangka hanya dilakukan sekali pada 5 maret 2010. Pencarian itu senilai Rp. 50 miliar dari total deposito Rp. 161 miliar. Sisa deposito senilai Rp. 111 miliar tersebut diduga dicairkan dengan cara yang tidak sesuai dengan prosedur perbankan yang berlaku dan tanpa persetujuan pihak manajemen. Kecurangan ini menyebabkan kerugian yang besar bagi PT Elnusa dan Bank Mega (Ruthmita, 2015)

Melihat maraknya kasus yang terjadi di Bank Perkreditan Rakyat (BPR) Good Corporate Governance saat ini diperlukan untuk memitigasi atau memperkecil tingkat terjadinya kecurangan kasus yang berada di BPR, international Monetary Find (IMF) memperkenalkan konsep GCG sebagai tata cara kelola perusahaan yang sehat (Renitha \& Dwijaputri, 2016). Menurut KNKG yang dibentuk tahun 1999 berdasarkan SK Menko Ekuin Nomor: KEP/31/M.EKUIN/08/1999 telah mengeluarkan pedoman Good Corporate Governance. Pedoman tersebut telah beberapa kali disempurnakan, terbaru pada tahun 2006 oleh KNKG (Komite Nasional Kebijakan Governance). Good Corporate Governance adalah suatu tata kelola Bank yang menerapkan prinsip - prinsip keterbukaan (transparency), akuntabilitas (accountability), pertanggungjawab (responsibility), independesni (independency), dan kewajaran (fairness). Prinsip prinsip tersebut diharapkan dapat menghasilkan keputusan yang lebih optimal 
dan jika tata kelola perusahaan baik, hal tersebut menunjukkan kecendrungan tanggung jawab perusahaan yang lebih besar (Rambo, 2013). Indonesian Institute of Corporate Governance Good Corporate Governance memiliki tujuan yaitu meningkatkan citra perusahaan dimata masyarakat, menarik minat investor, sebagai tuntutan dalam persaingan global, dapat pula meminimalkan biaya penyalahgunaan wewenang dalam perusahaan serta meminimalkan risiko yang timbul akibat buruknya tata kelola perusahaan (Ramdhaningsih \& karya utama, 2013).

Penerapan Good Corporate Governance yang baik merupakan sebuah konsep yang menenkankan pentingnya hak pemegang saham untuk memperoleh informasi dengan benar, akurat, dan tepat waktu. Selain itu juga menunjukan kewajiban perusahaan untuk mengungkapkan (disclosure) semua informasi kinerja keuangan secara akurat, tepat waktu, dan transparan. Oleh karena itu, baik perusahaan publik maupun tertutup harus memandang good corporate governance (GCG) bukan sebagai aksesoris belaka tetapi juga sebagai upaya peningkatan kinerja dan nilai perusahaan (Sianggono \& H. Mustamu, 2018). Krenn (2014) menyatakan sebuah tata kelola perusahaan yang baik dirancang untuk mengatasi kekurangan dalam sistem tata kelola perusahaan dan untuk meningkatkan kualitas tata kelola perusahaan secara keseluruhan.

The Organization for Economic Co-operation and Development (OECD) mengungkapkan bahwa manfaat dari GCG salah satunya adalah melancarkan proses pengambilan keputusan, meningkatkan efisiensi, serta terciptanya budaya kerja yang lebih sehat sehingga kinerja perusahaan akan mengalami peningkatan. Darwis, (2009) Berbagai penelitian dilakukan untuk mengetahui hubungan antara GCG terhadap kinerja perbankan. Seperti penelitin yang dilakukan oleh Adebayo et al, (2014) mengemukakan bahwa praktik GCG meningkatkan transparansi perusahaan, menjamin akuntabilitas dan meningkatkan profitabilitas, hasil secara umum bahwa GCG memberikan pengaruh bagi kinerja perusahaan.

Hasil penelitian dari Ben et al, (2015) mengemukakan bahwa adanya hubungan antara corporate governance dengan kinerja perbankan. Norwani et al, (2016) menyatakan bahwa kegagalan corporate governance akan menimbulkan kegagalan pula pada kinerja keuangan. Renitha \& Dwijaputri, (2016) menyatakan bahwa penerapan prinsip-prinsip GCG berpengaruh pada kinerja BPR. Berdasarkan dari hasil penelitan sebelumnya dapat disimpulkan bahwa penerapan GCG berpengaruh terhadap kinerja perbankan. Mengacu pada hasil penelitian sebelumnya, semakin baik penerapan GCG maka semakin baik pula kinerja pada bank tersebut.

Transparansi adalah memberikan informasi secara terbuka dan jujur kepada stakeholders berdasarkan pertimbangan, bahwa stakeholders memiliki hak untuk mengetahui secara terbuka dan menyeluruh atas pertanggungjawaban perusahaan dalam pengelolaan sumber daya yang dipercayakan kepadanya. Keterbukaan dalam pengungkapan informasi mengenai perusahaan akan meningkatkan kepercayaan stakeholders terhadap perusahaan, sehingga kinerja perusahaan diharapkan akan menjadi lebih baik. Penelitian yang dilakukan oleh Dewi \& Dwijaputri, (2014) prinsip good corporate governance berpengaruh positif terhadap kinerja. Rahmandy (2012) melakukan penelitian mengenai penerapan 
prinsip Good Corporate Governance (GCG) pada PT Bank Tabungan Negara (Persero) Tbk mengatakan bahwa penerapan prinsip GCG akan meningkatkan kinerja perusahaan. Hal yang serupa juga dipaparkan dalam penlitian Pratiwi \& Setiawan, (2014), transparansi berpengaruh positif terhadap kinerja. Sesuai dengan agency theory, hal ini menunjukkan bahwa semakin transparan BPR dalam mengungkapkan informasi mengenai keadaan BPR menyebabkan peningkatan kepercayaan prinsipal, maka kinerja BPR tersebut akan meningkat pula. Berdasarkan uraian tersebut maka rumusan hipotesis pertama dalam penelitian ini sebagai berikut.

$\mathrm{H}_{1}$ : Transparansi berpengaruh positif pada kinerja Bank Perkreditan Rakyat di Kabupaten Badung.

Akuntabilitas adalah pertanggungjawaban perusahaan atas kinerja secara transparan dan wajar kepada stakeholders. Untuk itu perusahaan harus dikelola secara benar, terukur dan sesuai dengan kepentingan perusahaan dengan tetap memperhitungkan kepentingan stakeholders, yang pada akhirnya akan meningkatkan perusahaan. Berdasarkan penelitian yang dilakukan oleh Angayana, (2019), prinsip akuntabilitas berpengaruh positif pada kinerja keuangan LPD Kota Denpasar. Hal tersebut sejalan dengan hasil penelitian yang dilakukan oleh Khrisna, (2017) yang mendapat hasil bahwa akuntabilitas berpengaruh positif pada kinerja keuangan LPD.

Sesuai dengan agency theory, hal ini menunjukkan bahwa semakin jelas wewenang dan fungsi pelaksanaan serta pertanggungjawaban struktur organisasi dalam BPR maka pengelolaan BPR akan terlaksana secara efektif dan meningkatkan kepercayaan prinsipal sehingga pada akhirnya meningkatkan kinerja BPR. Berdasarkan uraian tersebut maka rumusan hipotesis kedua dalam penelitian ini sebagai berikut.

$\mathrm{H}_{2}$ : Akuntabilitas berpengaruh positif pada kinerja Bank Perkreditan Rakyat di Kabupaten Badung.

Responsibilitas adalah sikap perusahaan dalam mengelola usahanya berdasarkan peraturan perundang-undangan yang berlaku. Untuk meningkatkan kinerjanya, perusahaan harus memahami dan memathui peraturan serta melaksanakan tanggung jawab terhadap stakeholders sehingga dapat terpelihara kesinambungan usaha dalam jangka panjang. Penelitian yang dilakukan oleh Sawitri (2017) mendapatkan hasil bahwa responsibilitas memiliki pengaruh positif pada kinerja Bank Perkreditan Rakyat (BPR) di Kota Denpasar. Hal serupa juga ditemukan dalam penelitian yang dilakukan oleh Pratiwi \& Setiawan, (2014) mendapatkan hasil responsibilitas good corporate governance pada kinerja berbasis Balanced Scorecard memiliki pengaruh positif pada kinerja keuangan LPD di Kota Denpasar.

Sesuai dengan agency theory, hal ini menunjukkan bahwa dengan mematuhi segala peraturan yang ada serta melaksanakan tanggungjawab terhadap prinsipal dapat memberi dampak pada pertumbuhan BPR yang berdampak pada meningkatnya kinerja BPR. Berdasarkan uraian tersebut maka rumusan hipotesis ketiga dalam penelitian ini sebagai berikut.

$\mathrm{H}_{3}$ : Responsibilitas berpengaruh positif pada kinerja Bank Perkreditan Rakyat di Kabupaten Badung. 
Independensi adalah sikap perusahaan dalam mengambil keputusan tanpa terikat dengan pihak manapun atau pihak yang mendominasi. Untuk meningkatkan kinerjanya, perusahaan harus bersikap secara objektif atau bebas dari kepentingan pihak yang merugikan perusahaan. Penelitian yang dilakukan oleh Sandraningsih (2015) mendapatkan hasil independensi memiliki pengaruh positif pada kinerja keuangan LPD di kecamatan Abiansemal Kabupaten Badung. Hal serupa juga ditemukan dalam penelitian yang dilakukan oleh Rahmatika \& Agusti, (2015) mendapatkan hasil independensi memiliki pengaruh positif dari penerapan kemandirian (independency) terhadap kinerja.

Sesuai dengan agency theory, hal ini menunjukkan dengan tidak adanya benturan kepentingan dalam pengelolaan BPR dapat bedampak pada meningkatnya kepercayaan prinsipal serta kinerja BPR dan memastikan bahwa BPR telah bersikap objektif dalam pengelolaanya. Berdasarkan uraian tersebut maka rumusan hipotesis keempat dalam penelitian ini sebagai berikut.

$\mathrm{H}_{4}$ : Independensi berpengaruh positif pada kinerja Bank Perkreditan Rakyat di Kabupaten Badung.

Kewajaran adalah keadilan dan kesetaran perusahaan dalam memenuhi kepentingan stakeholders yang timbul berdasarkan perjanjian dan peraturan perundang - undangan yang berlaku. Perusahaan harus senantiasa memperhatikan hak - hak para pemangku kepentingan berdasarkan asas kewajaran dan kesetaraan dalam rangka meningkatkan kinerja perusahaan kearah yang baik. Berdasarkan penelitian Dewi \& Dwijaputri, (2014) menyatakan bahwa kewajaran memiliki pengaruh positif terhadap kinerja keuangan LPD di Kabupaten Gianyar. Hal tersebut sejalan dengan penelitian yang dilakukan Renitha \& Dwijaputri, (2016) yang mendapatkan hasil bahwa prinsip kewajaran berpengaruh positif pada kinerja Bank Perkreditan Rakyat Kabupaten Gianyar.

Sesuai dengan agency theory, hal ini menunjukkan apabila pengelola BPR memperhatikan hak dari prinsipal serta memperlakukannya secara adil berdasarkan asas kewajaran dan kesetaraan maka dapat meningkatkan kinerja BPR. Berdasarkan uraian tersebut maka rumusan hipotesis kelima dalam penelitian ini sebagai berikut.

$\mathrm{H}_{5}$ : Kewajaran berpengaruh positif pada kinerja Bank Perkreditan Rakyat di Kabupaten Badung.

\section{METODE PENELITIAN}

Penelitian ini dilakukan pada seluruh BPR yang berada di Wilayah Kabupaten Badung, dengan mengakses laman www.ojk.go.id untuk mendapatkan informasi yang diperulkan tentang BPR di wilayah Badung. Objek dari penelitian ini adalah kinerja berbasis balanced scorecard pada Bank Perkreditan Rakyat (BPR) di Kabupaten Badung dan pengaruh Good Corporate Governance pada kinerja berbasis Balance Scorecard.

Populasi dalam penelitian ini adalah Bank perkreditan Rakyat (BPR) di wilayah Badung. Lokasi ini dipilih karena Bank Perkreditan Rakyat yang terdapat di Kabupaten Badung tercatat menjadi BPR yang memiliki jumlah terbnyak pertama di Bali, sehingga potensi pemberian kredit kepada masyarakat cukup tinggi. Berikut adalah julmah data BPR yang diperoleh dari Otoritas Jasa Keuangan yang terdapat di Kabupaten Badung. Metode yang digunakan dalam 
penelitian ini adalah metode purposive sampling, dimana sampel ditentukan dengan pertimbangan-pertimbangan tertentu yang sesuai dengan staf yang ditentukan.

Responden yang dipilih dalam penelitian ini adalah Staf Bank perkeditan Rakyat (BPR). Staf bagian keuangan dan staf bagian umum dipilih sebagai responden karena kegiatan operasionalnya paling dekat dengan impelemtasi GCG, dimana staf bagian keuangan memberikan keyakinan atas kualitas informasi keuangan dengan memberikan pendapat yang independen atas kewajaran penyajian informasi pada laporan keuangan. Sedangkan staf bagian umum lebih memahami prosedur di tempat kerja, karena saling berkaitan dengan semua staf di lain. Sampel sebanyak 74, masing - masing BPR terdiri dari 2 orang responden yaitu staf bagian keuangan dan staf bagian umum.

Alat analisis data yang digunakan adalah uji koefisien determinasi $\mathrm{R}^{2}$, uji F (kelayakan model), uji statistic t (uji signifikansi parameter individual) yang bertujuan untuk menguji hipotesis dengan menggunakan regresi linear berganda melalui program computer SPSS dengan rumus sebagai berikut.

$\mathrm{Y}={ }_{-} \alpha+\beta_{1} \mathrm{X} 1+\beta_{2} \mathrm{X} 2+\beta_{3} \mathrm{X} 3+\beta_{4} \mathrm{X} 4+\beta_{5} \mathrm{X} 5$

Keterangan :

$\begin{array}{ll}\mathrm{Y} & =\text { Variabel terikat (kinerja) } \\ \mathrm{A} & =\text { Konstanta } \\ \beta_{1} \beta_{2} \beta_{3} \beta_{4} \beta_{5} \beta_{6} & =\text { Koefisien Regresi untuk } \mathrm{X}_{1}, \mathrm{X}_{2}, \mathrm{X}_{3}, \mathrm{X}_{4}, \mathrm{X}_{5} \\ \mathrm{X}_{1} & =\text { Transparansi } \\ \mathrm{X}_{2} & =\text { Akuntabilitas } \\ \mathrm{X}_{3} & =\text { Responsibitas } \\ \mathrm{X}_{4} & =\text { Independensi } \\ \mathrm{X}_{5} & =\text { Kewajaran }\end{array}$

Untuk menyelesaikan analisis data ini secara keseluruhan, digunakanprogram SPSS dan semua hasil output data yang dihasilkan kemudia diinterpretasikan suatu per suatu termasuk di dalamnya menentukan koefisien korelasi (R) untuk mengukur tingkat hubungan antara variable bebas dan variable terikat serta koefisein determinasi $\left(R^{2}\right)$ untuk mengukur pengaruh antara variable bebas dan variable terikat.

\section{HASIL DAN PEMBAHASAN}

Statistik deskriptif menyajikan informasi mengenai karakteristik variabel yang diteliti. Statistik deskriptif menunjukkan informasi mengenai jumlah pengamatan, nilai minimum, nilai maksimum, nilai mean, dan standar deviasi.

Berdasarkan Tabel 1, dapat diperoleh nilai minimun dari jumlah skor jawaban responden untuk variabel transparansi adalah 2,00 dan nilai maksimumnya adalah 4,00. Nilai rata-rata sebesar 3,2601 menunjukkan bahwa responden cenderung merasa setuju pada masing-masing item pernyataan dalam kuesioner. Standar deviasi sebesar 0,61299, berarti bahwa nilai standar deviasi lebih kecil dari nilai rata-ratanya.

Berdasarkan Tabel 1, dapat diperoleh nilai minimun dari jumlah skor jawaban responden untuk variabel akuntabilitas adalah 2,00 dan nilai maksimumnya adalah 4,00. Nilai rata-rata sebesar 3,2838 menunjukkan bahwa 
responden cenderung merasa setuju pada masing-masing item pernyataan dalam kuesioner. Standar deviasi sebesar 0,56180, berarti bahwa nilai standar deviasi lebih kecil dari nilai rata-ratanya. Tabel 1, berikut menyajikan hasil statistik deskriptif.

Tabel 1. Hasil Uji Deskriptif

\begin{tabular}{llllll}
\hline & & & & \multicolumn{2}{c}{ Std. } \\
& $\mathrm{N}$ & Minimum & Maximum & Mean & Deviation \\
\hline Transparansi & 74 & 2,00 & 4,00 & 3,2601 & 0,61299 \\
Akuntabilitas & 74 & 2,00 & 4,00 & 3,2838 & 0,56180 \\
Responsibilitas & 74 & 2,25 & 4,00 & 3,2601 & 0,54810 \\
Independensi & 74 & 2,00 & 4,00 & 3,1565 & 0,63497 \\
Kewajaran & 74 & 2,00 & 4,00 & 3,2196 & 0,62339 \\
Kinerja Perusahaan & 74 & 2,00 & 4,00 & 3,3576 & 0,55800 \\
Valid N (listwise) & 74 & & & &
\end{tabular}

Sumber: Data Penelitian, 2019

Berdasarkan Tabel 1, dapat diperoleh nilai minimun dari jumlah skor jawaban responden untuk variabel responsibilitas adalah 2,25 dan nilai maksimumnya adalah 4,00. Nilai rata-rata 3,2601 menunjukkan bahwa respoden cenderung merasa setuju pada masing-masing item pernyataan dalam kuesioner. Standar deviasi sebesar 0,54810, berarti bahwa nilai standar deviasi lebih kecil dari nilai rata-ratanya.

Berdasarkan Tabel 1, dapat diperoleh nilai minimun dari jumlah skor jawaban responden untuk variabel independensi adalah 2,00 dan nilai maksimumnya adalah 4,00. Nilai rata-rata 3,1565 menunjukkan bahwa responden cenderung merasa setuju pada masing-masing item pernyataan dalam kuesioner. Standar deviasi sebesar 0,63497, berarti bahwa nilai standar deviasi lebih kecil dari nilai rata-ratanya.

Berdasarkan Tabel 1, dapat diperoleh nilai minimun dari jumlah skor jawaban responden untuk variabel kewajaran adalah 2,00 dan nilai maksimumnya adalah 4,00. Nilai rata-rata 3,2196 menunjukkan bahwa responden cenderung merasa setuju pada masing-masing item pernyataan dalam kuesioner. Standar deviasi sebesar 0,62339, berarti bahwa nilai standar deviasi lebih kecil dari nilai rata-ratanya.

Berdasarkan Tabel 1, dapat diperoleh nilai minimun dari jumlah skor jawaban responden untuk variabel kinerja perusahaan adalah 2,00 dan nilai maksimumnya adalah 4,00. Nilai rata-rata 3,3576 menunjukkan bahwa resnponden cenderung merasa setuju pada masing-masing item pernyataan dalam kuesioner. Standar deviasi sebesar 055800, berarti bahwa nilai standar deviasi lebih kecil dari nilai rata-ratanya.

Nilai konstanta sebesar 2,283 menyatakan bahwa apabila variabel transparansi $\left(X_{1}\right)$, akuntabilitas $\left(X_{2}\right)$, responsibilitas $\left(X_{3}\right)$, independensi $\left(X_{4}\right)$ dan kewajaran $\left(\mathrm{X}_{5}\right)$ sama dengan nol, maka kinerja BPR pada Kabupaten Badung (Y) adalah sebesar 2,283 satuan.

Nilai koefisien regresi dari transparansi $\left(X_{1}\right)$, sebesar 0,652 menunjukan bahwa terdapat pengaruh positif antara variabel transparansi terhadap kinerja BPR di Kabupaten Badung sebesar 0,652. Hal ini berarti apabila variabel independen transparansi naik sebesar 1 satuan dengan asumsi bahwa variabel 
bebas lainnya konstan, maka variabel kinerja BPR di Kabupaten Badung akan mengalami peningkatan sebesar 0,652.

Nilai koefisien regresi dari akuntabilitas $\left(\mathrm{X}_{2}\right)$, sebesar 0,617 menunjukan bahwa terdapat pengaruh positif antara variabel akuntabilitas terhadap kinerja BPR di Kabupaten Badung sebesar 0,617. Hal ini berarti apabila variabel independen akuntabilitas naik sebesar 1 satuan dengan asumsi bahwa variabel bebas lainnya konstan, maka variabel kinerja BPR di Kabupaten Badung akan mengalami peningkatan sebesar 0,617. Hasil analisis regresi linier berganda disajikan pada Tabel 2.

Tabel 2. Hasil Analisis Regresi Linier Berganda

\begin{tabular}{|c|c|c|c|c|c|}
\hline \multirow[t]{2}{*}{ Model } & \multicolumn{2}{|c|}{$\begin{array}{l}\text { Unstandardized } \\
\text { Coefficients }\end{array}$} & \multicolumn{2}{|c|}{$\begin{array}{l}\text { Standardized } \\
\text { Coefficients }\end{array}$} & \multirow[b]{2}{*}{ Sig. } \\
\hline & $\mathrm{B}$ & Std. Error & Beta & $\mathrm{T}$ & \\
\hline (Constant) & 2,283 & 3,048 & & 0,749 & 0,457 \\
\hline Transparansi & 0,652 & 0,262 & 0,239 & 2,489 & 0,015 \\
\hline Akuntabuslitas & 0,617 & 0,288 & 0,207 & 2,143 & 0,036 \\
\hline Responsibilitas & 0,612 & 0,250 & 0,200 & 2,452 & 0,017 \\
\hline Independensi & 0,731 & 0,356 & 0,208 & 2,052 & 0,044 \\
\hline Kewajaran & 0,504 & 0,238 & 0,187 & 2,114 & 0,038 \\
\hline $\mathrm{R}$ & 0,846 & & & & \\
\hline R Square & 0,715 & & & & \\
\hline Adjusted R Square & 0,695 & & & & \\
\hline F Statistik & 34,202 & & & & \\
\hline Signifikansi Uji F & 0,000 & & & & \\
\hline
\end{tabular}

Sumber: Data Penelitian, 2019

Berdasarkan Tabel 2, dapat disusun persamaan regresi sebagai berikut. $Y=2,283+0,652 X_{1}+0,617 X_{2}+0,612 X_{3}+0,731 X_{4}+0,504 X_{5}$

Nilai koefisien regresi dari responsibilitas $\left(X_{3}\right)$, sebesar 0,612 menunjukan bahwa terdapat pengaruh positif antara variabel responsibilitas terhadap kinerja BPR di Kabupaten Badung sebesar 0,612. Hal ini berarti apabila variabel independen responsibilitas naik sebesar 1 satuan dengan asumsi bahwa variabel bebas lainnya konstan, maka variabel kinerja BPR di Kabupaten Badung akan mengalami peningkatan sebesar 0,612.

Nilai koefisien regresi dari independensi $\left(\mathrm{X}_{4}\right)$, sebesar 0,731 menunjukan bahwa terdapat pengaruh positif antara variabel independensi terhadap kinerja BPR di Kabupaten Badung sebesar 0,731. Hal ini berarti apabila variabel independen independensi naik sebesar 1 satuan dengan asumsi bahwa variabel bebas lainnya konstan, maka variabel kinerja BPR di Kabupaten Badung akan mengalami peningkatan sebesar 0,731.

Nilai koefisien regresi dari kewajaran $\left(X_{5}\right)$, sebesar 0,504 menunjukan bahwa terdapat pengaruh positif antara variabel kewajaran terhadap kinerja BPR di Kabupaten Badung sebesar 0,504. Hal ini berarti apabila variabel independen kewajaran naik sebesar 1 satuan dengan asumsi bahwa variabel bebas lainnya konstan, maka variabel kinerja BPR di Kabupaten Badung akan mengalami peningkatan sebesar 0,504.

Koefisien determinasi $\left(\mathrm{R}^{2}\right)$ digunakan untuk mengetahui dan mengukur kemampuan model dalam menerangkan variasi variabel independen. Berdasarkan Tabel 2, nilai Adjust $R$ Square sebesar 0,695 hal ini berarti 69,5 
persen variasi kinerja BPR di Kabupaten Badung $(Y)$ dipengaruhi oleh variabel transparansi $\left(X_{1}\right)$, akuntabilitas $\left(X_{2}\right)$, responsibilitas $\left(X_{3}\right)$, independensi $\left(X_{4}\right)$ dan kewajaran $\left(X_{5}\right)$, sisanya sebesar 30,5 persen dipengaruhi oleh faktor lain di luar model penelitian.

Koefisien korelasi (R) digunakan untuk mengukur tingkat hubungan antara variable bebas dan variable terikat serta koefisein determinasi $\left(R^{2}\right)$ untuk mengukur pengaruh antara variable bebas dan variable terikat.

Berdasarkan hasil analisis pada Tabel 2, diperoleh koefisien korelasi berganda sebesar $\mathrm{R}=0,846$. Ini berarti ada hubungan yang sangat kuat secara bersama-sama antara variable transparansi $\left(X_{1}\right)$, akuntabilitas $\left(X_{2}\right)$, responsibilitas $\left(X_{3}\right)$, independensi $\left(X_{4}\right)$ dan kewajaran $\left(X_{5}\right)$ dengan kinerja BPR di Kabupaten Badung (Y).

Uji F bertujuan untuk mengetahui kelayakan model regresi linier berganda sebagai alat analisis yang menguji pengaruh variabel bebas terhadap variabel terikat. Hasil uji F dapat dijelaskan dengan nilai p-value. Signifikansi F sebesar 0,000 lebih kecil dari 0,05. Hasil uji $\mathrm{F}$ yang di analisis dengan menggunakan program SPSS diperoleh nilai $F_{\text {hitung }}$ sebesar 34,202 dengan signifkansi sebesar $0,000<0,05$, maka dapat disimpulkan bahwa pada kelompok yang diuji memiliki perbedaan yang nyata (signifikan). Hasil ini mempunyai arti bahwa ada pengaruh signifikan antara trasnparansi, akuntabilitas, responsibilitas, independensi dan kewajaran terhadap kinerja BPR di Kabupaten Badung. Dengan demikian, maka model dianggap layak uji dan pembuktian hipotesis dapat dilanjutkan.

Transparansi merupakan memberikan informasi secara terbuka dan jujur kepada stakeholders berdasarkan pertimbangan, bahwa stakeholders memiliki hak untuk mengetahui secara terbuka dan menyeluruh atas pertanggungjawaban perusahaan dalam pengelolaan sumber daya yang dipercayakan kepadanya. Berdasarkan hasil pengujian (uji t) dalam penelitian ini, didapatkan hasil bahwa transparansi mempunyai nilai koefisien regrsi potitif 0,652 dan Sig t 0,015 < 0,050 . Hasil pengujian tersebut menunjukkan bahwa hipotesis pertama $\left(\mathrm{H}_{1}\right)$ transparansi mempunyai pengaruh yang positif terhadap kinerja pada BPR di Kabupaten Badung diterima. Hal ini berarti bahwa semakin tinggi transparansi maka akan menyebabkan meningkatkan kinerja BPR pada Kabupaten Badung. Berkaitan dengan teori agency, dengan perusahaan mampu memberikan informasi secara terbuka dan jujur kepada stakeholder maka nantinya akan meningkatkan kinerja BPR di Kabupaten Badung, sebaliknya jika informasi yang diberikan perusahaan tidak terbuka dan tidak jurjur kepada stakeholder maka nantinya akan menurunkan kinerja BPR di Kabupaten Badung. Hal ini juga didukung oleh teori stewardship dimana teori yang menggambarkan situasi dimana para manajer tidaklah termotivasi oleh tujuan individu tetapi lebih ditujukan pada sasaran hasil utama mereka untuk kepentingan organisasi, sehingga teori ini mempunyai dasar psikologi dan sosiologi yang telah dirancang dimana para eksekutif sebagai steward termotivasi untuk bertindak sesuai keinginan principal, sehingga para manajer akan selalu mengutamakan kepentingan perusahaan dengan selalu memberikan berusaha memberikan 
informasi secara terbuka dan jujur kepada stakeholder untuk meningkatkan kinerja

Hasil ini mendukung penelitian yang dilakukan oleh Penelitian yang dilakukan oleh (Dewi \& Dwijaputri, 2014) prinsip good corporate governance berpengaruh positif terhadap kinerja. Rahmandy (2012) melakukan penelitian mengenai penerapan prinsip good corporate governance (GCG) pada PT Bank Tabungan Negara (Persero) Tbk mengatakan bahwa penerapan prinsip GCG akan meningkatkan kinerja perusahaan. Hal yang serupa juga dipaparkan dalam penlitian (Pratiwi \& Setiawan, 2014), transparansi berpengaruh positif terhadap kinerja.

Akuntabilitas adalah pertanggungjawaban perusahaan atas kinerja secara transparan dan wajar kepada stakeholders. Berdasarkan hasil pengujian (uji t) dalam penelitian ini, didapatkan hasil bahwa akuntabilitas mempunyai nilai koefisien regrsi potitif 0,617 dan Sig t 0,036 $<0,050$. Hasil pengujian tersebut menunjukkan bahwa hipotesis kedua $\left(\mathrm{H}_{2}\right)$ akuntabilitas mempunyai pengaruh yang positif terhadap kinerja pada BPR di Kabupaten Badung diterima. Hal ini berarti bahwa semakin tinggi akuntabilitas maka akan menyebabkan meningkatkan kinerja BPR pada Kabupaten Badung. Berkaitan dengan teori agency, jika perusahaan mampu memberikan pertanggungjawaban atas kinerja secara transparan dan wajar kepada stakeholders maka nantinya akan meningkatkan kinerja BPR di Kabupaten Badung, sebaliknya jika perusahaan tidak mampu memberikan pertanggungjawaban atas kinerja secara transparan dan wajar kepada stakeholders maka nantinya akan menurunkan kinerja BPR di Kabupaten Badung. Hal ini juga didukung oleh teori stewardship dimana teori yang menggambarkan situasi dimana para manajer tidaklah termotivasi oleh tujuan individu tetapi lebih ditujukan pada sasaran hasil utama mereka untuk kepentingan organisasi, sehingga teori ini mempunyai dasar psikologi dan sosiologi yang telah dirancang dimana para eksekutif sebagai steward termotivasi untuk bertindak sesuai keinginan principal, sehingga para manajer akan selalu mengutamakan kepentingan perusahaan dengan selalu memberikan pertanggungjawaban atas kinerja secara transparan dan wajar kepada stakeholders untuk meningkatkan kinerja

Hasil ini mendukung penelitian yang dilakukan oleh Angayana, (2019), prinsip akuntabilitas berpengaruh positif pada kinerja keuangan LPD Kota Denpasar. Hal tersebut sejalan dengan hasil penelitian yang dilakukan oleh Khrisna, (2017) yang mendapat hasil bahwa akuntabilitas berpengaruh positif pada kinerja keuangan LPD.

Responsibilitas adalah sikap perusahaan dalam mengelola usahanya berdasarkan peraturan perundang - undangan yang berlaku. Berdasarkan hasil pengujian (uji t) dalam penelitian ini, didapatkan hasil bahwa responsibilitas mempunyai nilai koefisien regrsi potitif 0,612 dan Sig t 0,017 < 0,050. Hasil pengujian tersebut menunjukkan bahwa hipotesis ketiga $\left(\mathrm{H}_{3}\right)$ responsibilitas mempunyai pengaruh yang positif terhadap kinerja pada BPR di Kabupaten Badung diterima. Hal ini berarti bahwa semakin tinggi responsibilitas maka akan menyebabkan meningkatkan kinerja BPR pada Kabupaten Badung. Berkaitan dengan teori agency, jika perusahaan mampu memahami dan mematuhi peraturan serta melaksanakan tanggung jawab terhadap stakeholders sehingga 
dapat terpelihara kesinambungan usaha dalam jangka panjang maka nantinya akan meningkatkan kinerja BPR di Kabupaten Badung, sebaliknya jika perusahaan tidak mampu memahami dan mematuhi peraturan serta melaksanakan tanggung jawab terhadap stakeholders maka nantinya akan menurunkan kinerja BPR di Kabupaten Badung. memberikan informasi secara terbuka dan jujur kepada stakeholder. Hal ini juga didukung oleh teori stewardship dimana teori yang menggambarkan situasi dimana para manajer tidaklah termotivasi oleh tujuan individu tetapi lebih ditujukan pada sasaran hasil utama mereka untuk kepentingan organisasi, sehingga teori ini mempunyai dasar psikologi dan sosiologi yang telah dirancang dimana para eksekutif sebagai steward termotivasi untuk bertindak sesuai keinginan principal, sehingga para manajer akan selalu berusaha untuk memahami dan mematuhi peraturan serta melaksanakan tanggung jawab terhadap stakeholders holders untuk meningkatkan kinerja

Hasil ini mendukung penelitian yang dilakukan oleh Sawitri (2017) mendapatkan hasil bahwa responsibilitas memiliki pengaruh positif pada kinerja Bank Perkreditan Rakyat (BPR) di Kota Denpasar. Hal serupa juga ditemukan dalam penelitian yang dilakukan oleh (Pratiwi \& Setiawan, 2014) mendapatkan hasil responsibilitas good corporate governance pada kinerja berbasis Balanced Scorecard memiliki pengaruh positif pada kinerja keuangan LPD di Kota Denpasar.

Independensi adalah sikap perusahaan dalam mengambil keputusan tanpa terikat dengan pihak manapun atau pihak yang mendominasi. Berdasarkan hasil pengujian (uji t) dalam penelitian ini, didapatkan hasil bahwa independensi mempunyai nilai koefisien regrsi potitif 0,731 dan Sig t 0,044<0,050. Hasil pengujian tersebut menunjukkan bahwa hipotesis keempat $\left(\mathrm{H}_{4}\right)$ independensi mempunyai pengaruh yang positif terhadap kinerja pada BPR di Kabupaten Badung diterima. Hal ini berarti bahwa semakin tinggi independensi maka akan menyebabkan meningkatkan kinerja BPR pada Kabupaten Badung. Berkaitan dengan teori agency, jika perusahaan mampu bersikap secara objektif atau bebas dari kepentingan pihak yang merugikan perusahaan maka nantinya akan meningkatkan kinerja BPR di Kabupaten Badung, sebaliknya jika perusahaan tidak mampu bersikap secara objektif atau bebas dari kepentingan pihak yang merugikan perusahaan maka nantinya akan menurunkan kinerja BPR di Kabupaten Badung. Hal ini juga didukung oleh teori stewardship dimana teori yang menggambarkan situasi dimana para manajer tidaklah termotivasi oleh tujuan individu tetapi lebih ditujukan pada sasaran hasil utama mereka untuk kepentingan organisasi, sehingga teori ini mempunyai dasar psikologi dan sosiologi yang telah dirancang dimana para eksekutif sebagai steward termotivasi untuk bertindak sesuai keinginan principal, sehingga para manajer akan selalu bersikap secara objektif atau bebas dari kepentingan pihak yang merugikan perusahaan untuk meningkatkan kinerja

Hasil ini mendukung penelitian yang dilakukan oleh sandraningsih (2015) mendapatkan hasil independensi memiliki pengaruh positif pada kinerja keuangan LPD di kecamatan Abiansemal Kabupaten Badung. Hal serupa juga ditemukan dalam penelitian yang dilakukan oleh (Rahmatika \& Agusti, 2015) 
mendapatkan hasil independensi memiliki pengaruh positif dari penerapan kemandirian (independency) terhadap kinerja.

Kewajaran adalah keadilan dan kesetaran perusahaan dalam memenuhi kepentingan stakeholders yang timbul berdasarkan perjanjian dan peraturan perundang - undangan yang berlaku. Berdasarkan hasil pengujian (uji t) dalam penelitian ini, didapatkan hasil bahwa kewajaran mempunyai nilai koefisien regrsi potitif 0,504 dan Sig t 0,038 < 0,050. Hasil pengujian tersebut menunjukkan bahwa hipotesis kelima $\left(\mathrm{H}_{5}\right)$ kewajaran mempunyai pengaruh yang positif terhadap kinerja pada BPR di Kabupaten Badung diterima. Hal ini berarti bahwa semakin tinggi kewajaran maka akan menyebabkan meningkatkan kinerja BPR pada Kabupaten Badung. Berkaitan dengan teori agency, jika perusahaan mampu memberikan keadilan dan kesetaran dalam memenuhi kepentingan stakeholders maka nantinya akan meningkatkan kinerja BPR di Kabupaten Badung, sebaliknya jika perusahaan tidak mampu memberikan keadilan dan kesetaran dalam memenuhi kepentingan stakeholder maka nantinya akan menurunkan kinerja BPR di Kabupaten Badung. Hal ini juga didukung oleh teori stewardship dimana teori yang menggambarkan situasi dimana para manajer tidaklah termotivasi oleh tujuan individu tetapi lebih ditujukan pada sasaran hasil utama mereka untuk kepentingan organisasi, sehingga teori ini mempunyai dasar psikologi dan sosiologi yang telah dirancang dimana para eksekutif sebagai steward termotivasi untuk bertindak sesuai keinginan principal, sehingga para manajer akan selalu mengutamakan kepentinga perusahaan dengan selalu menerapkan keadilan dan kesetaran dalam memenuhi kepentingan stakeholder untuk meningkatkan kinerja

Hasil ini mendukung penelitian yang dilakukan oleh sandraningsih (2015) mendapatkan hasil independensi memiliki pengaruh positif pada kinerja keuangan LPD di kecamatan Abiansemal Kabupaten Badung. Hal serupa juga ditemukan dalam penelitian yang dilakukan oleh (Dewi \& Dwijaputri, 2014) menyatakan bahwa kewajaran memiliki pengaruh positif terhadap kinerja keuangan LPD di Kabupaten Gianyar. Hal tersebut sejalan dengan penelitian yang dilakukan (Renitha \& Dwijaputri, 2016) yang mendapatkan hasil bahwa prinsip kewajaran berpengaruh positif pada kinerja Bank Perkreditan Rakyat Kabupaten Gianyar.

\section{SIMPULAN}

Penelitian ini memberikan gambaran serta wawasan yang lebih luas mengenai good corporate governance dan memperoleh pemahaman yang lebih baik tentang teori keagenan dan teori stewardship serta dampaknya pada kinerja bank. Secara lebih spesifik penelitian ini memberi pemahaman yang lebih luas tentang prinsip - prinsip GCG yang mempengaruhi kinerja bank. Hasil uji dalam penelitian ini menemukan bahwa secara statistik transparansi, akuntabilitas, responsibilitas, independensi dan kewajaran memiliki pengaruh positif pada kinerja kinerja BPR di Kabupaten Badung. Penelitian ini memberikan implikasi bagi BPR di Kabupaten Badung sebagai pertimbangan dan pengetahuan mengenai kinerja serta faktor-faktor yang memengaruhinya. Perusahaan dapat mengevaluasi transparansi, akuntabilitas, responsibilitas, independensi dan kewajaran, karena hal tersebut dapat mempengaruhi kinerja BPR pada Kabupaten Badung. 


\section{REFERENSI}

Adebayo et al. (2014). Good Corporate Governance and Organisational Performance: An Empirical Analysis Adebayo, Mudashiru Department of Accounting and Finance Faculty of Management Sciences Lagos State University Nigeria Ibrahim, A . O . Bakare Department of Economics Facult. 4(7), 170-178.

Andriyani, P., \& Dwija, A. (2016). Pengaruh Good Corporate Governance Pada Kinerja Berbasis Balanced Scorecard. E-Jurnal Akuntansi, 15(2), 832-846.

Angayana, I. P. N. (2019). Pengaruh Prinsip - Prinsip Good Governance dan Budaya Organisasi Terhadap Kinerja Keuangan Lembaga Perkreditan Desa Kota Denpasar. E-Jurnal Akuntansi Universitas Udayana, 29(1), 1984-2000.

Araujo, E. De, \& Christiananta, B. (2013). Confirmatory factor analysis on strategic leadership, corporate culture, good corporate governance and company performance. Social Sciences and Humanities, 4(4), 487-495. Retrieved from http:// www.savap.org.pk/journals/ARInt./Vol.4(4)/2013(4.4-52).pdf

Ben et al. (2015). Pengaruh Good Corporate Governance Terhadap Kinerja Bank Perkreditan Rakyat Di Kota Bandung. 1-10.

Brahmananda, I. B., \& Suputra, I. D. G. D. (2017). Analisis Komparatif Tingkat Kesehatan Bank Antara CAMELS dan RGEC PT Bank BPD Bali Tahun 20122014. Jurnal Akuntansi Universitas Udayana, 19(1), 51-80.

Darwis, H. (2009). Pengaruh Mekanisme Corporate Governance Terhadap Kinerja Perusahaan. Jurnal Akuntansi Dan Manajemen, STIE YKPN Yogyakarta, 19(3), 155-172.

Dewi, K. K., \& Dwijaputri, I. M. A. (2014). Pengaruh Penerapan Prinsip-Prinsip Gcg Pada Kinerja Keuangan Lembaga Perkreditan Desa Kabupaten Gianyar Bali. E-Jurnal Akuntansi Universitas Udayana 7.3 (2014): 559-573, 7(3), 559-573.

Fitriyani, D., Tiswiyanti, W., \& Prasetyo, E. (2017). Good Corporate Governance Dan Dampaknya Terhadap Kinerja Berdasarkan Balanced Scorecard. Jurnal Akuntansi, 20(3), 91-103. https:/ / doi.org/10.24912/ja.v20i3.7

Khrisna. (2017). Pengaruh Prinsip-Prinsip Good Corporate Governance Terhadap Kinerja Keuangan Lembaga Perkreditan Desa (Lpd) Di Kota Denpasar. EJurnal Akuntansi Universitas Udayana, 21(2), 970-995.

Norwani et al. (2016). Corporate regulations and quality of financial reporting: A proposed study. International Journal of Economics and Financial Issues, 6(7Special Issue), 132-136.

Pratiwi, I., \& Setiawan, P. (2014). Pengaruh Kesadaran Wajib Pajak, Kualitas Pelayanan, Kondisi Keuangan Perusahaan, Dan Persepsi Tentang Sanksi Perpajakan Pada Kepatuhan Wajib Pajak Reklame Di Dinas Pendapatan Kota Denpasar. E-Jurnal Akuntansi, 6(1), 139-153.

Rahmatika, N., \& Agusti, R. (2015). Pengaruh Penerapan Prinsip-Prinsip Good Corporate Governance Terhadap Kinerja Keuangan Perusahaan (Studi pada PT Angkasa Pura II). Jurnal Akuntansi, 3(2), 148-159.

Rambo, C. M. (2013). Authority' S Corporate Governance. 7(3), 77-93.

Ramdhaningsih \& karya utama. (2013). Pengaruh Indikator Good Corporate Governance Dan Profitabilitas Pada Pengungkapan Corporate Social Responsibility. E-Jurnal Akuntansi, 3(2), 368-386. 
Renitha, \& Dwijaputri, I. M. A. (2016). Pengaruh Penerapan Prinsip-Prinsip Good Corporate Governance Pada Kinerja Bank Perkreditan Rakyat Kabupaten Gianyar. E-Jurnal Akuntansi, 16(1), 101-128.

Sianggono, A., \& H. Mustamu, R. (2018). Penerapan Prinsip-Prinsip Good Corporate Governance Pada Perusahaan Keluarga Dalam Industri Mebel. Jurnal Program Manajemen Bisnis, Program Studi Manajemen, Universitas Kristen Petra, 6(1), 1-6. 